\title{
Antihypertensives and COVID-19: Literature review
}

Anti-hipertensivos e COVID-19: Revisão de literatura

Antihipertensivos y COVID-19: Revisión de la literatura

Thais Cristina Loyola da Silva

ORCID: https://orcid.org/0000-0003-1605-9923 Liga Norte Riograndense Contra o Câncer, Brazil

E-mail: thaiscristinaloyola@outlook.com

Pedro Vilar de Oliveira Villarim

ORCID: https://orcid.org/0000-0002-9504-8589 Liga Norte Riograndense Contra o Câncer, Brazil E-mail: pedrovilar@ufrn.edu.br

Alyne Barreto Mesquita de Goés ORCID: https://orcid.org/0000-0001-5187-6174 Liga Norte Riograndense Contra o Câncer, Brazil

E-mail: alynebarreto2@ hotmail.com

Vitória Ribeiro Dantas Marinho

ORCID: https://orcid.org/0000-0002-8514-1560 Liga Norte Riograndense Contra o Câncer, Brazil

E-mail: vitoriardmarinho@hotmail.com

Natália Marcelino Araújo

ORCID: https://orcid.org/0000-0003-3143-6299

Liga Norte Riograndense Contra o Câncer, Brazil

E-mail: nataliamarcelino4@gmail.com

André Luiz Costa e Silva

ORCID: https://orcid.org/0000-0001-7255-3833

Liga Norte Riograndense Contra o Câncer, Brazil

E-mail: andreluizcostaesilva@hotmail.com

Amália Cinthia Meneses Rêgo

ORCID: https://orcid.org/0000-0002-0575-3752

Universidade Potiguar, Brasil

E-mail: regoamalia@gmail.com

Irami Araújo-Filho

ORCID: https://orcid.org/0000-0003-2471-7447 Universidade Potiguar, Brasil

Universidade Federal do Rio Grande do Norte, Brasil E-mail: irami.filho@uol.com.br

\begin{abstract}
Hypertensive patients with COVID-19 are susceptible to complications of the disease, so this study aimed to analyze the action of drugs that act on Angiotensin (TA) in the presence of COVID-19 in comparison with other antihypertensives, as well as to identify the main ones. evidence on the subject presented so far. It is an integrative literature review containing 34 articles selected according to the inclusion criteria, between January / 2020 to February / 2021, in the PubMed, Embase, Scopus and Web of Science databases. The results do not show a causal relationship between the increase in COVID-19 infection and the use of RAAS inhibitors, but a possible protective effect of these against the severe manifestation of the disease due to the inhibition of the pro-inflammatory diseases of AT II. Thus, about $2 / 3$ of the studies defended the continuity of use and the protection factor of RAAS blockers to the detriment of the other classes of antihypertensive drugs that do not modulate RAAS. It was found, then, that antihypertensive treatment should be maintained, as it does not worsen the prognosis in the face of Sars-CoV-2 infection. However, the studies are mainly observational and, therefore, cannot establish strong causal relationships. For this reason, robust randomized controlled trials are needed to better understand this topic.
\end{abstract}

Keywords: Antihypertensive agents; Angiotensin-converting enzyme inhibitors; Hypertension; SARS-CoV-2; COVID-19.

\section{Resumo}

Pacientes hipertensos com COVID-19 são suscetíveis às complicações da doença, portanto este estudo teve como objetivo analisar a ação de fármacos que atuam sobre a Angiotensina (AT) na presença de COVID-19 em comparação com outros anti-hipertensivos, bem como identificar os principais. evidências sobre o assunto apresentadas até o momento. Trata-se de uma revisão integrativa da literatura contendo 34 artigos selecionados segundo os critérios de inclusão, entre janeiro / 2020 a fevereiro / 2021, nas bases de dados PubMed, Embase, Scopus e Web of Science. Os resultados não mostram uma relação causal entre o aumento da infecção por COVID-19 e o uso de inibidores do RAAS, 
mas um possível efeito protetor destes contra a manifestação grave da doença devido à inibição das doenças próinflamatórias do AT II. Assim, cerca de $2 / 3$ dos estudos defenderam a continuidade do uso e o fator de proteção dos bloqueadores RAAS em detrimento das demais classes de anti-hipertensivos que não modulam o RAAS. Verificou-se, então, que o tratamento anti-hipertensivo deve ser mantido, pois não piora o prognóstico diante da infecção pelo SarsCoV-2. No entanto, os estudos são principalmente observacionais e, portanto, não podem estabelecer relações causais fortes. Por esse motivo, ensaios clínicos randomizados robustos são necessários para melhor compreender este tópico. Palavras-chave: Anti-hipertensivos; Inibidores da enzima conversora da angiotensina; Hipertensão, SARS-CoV-2; COVID-19.

\section{Resumen}

Los pacientes hipertensos con COVID-19 son susceptibles a complicaciones de la enfermedad, por lo que este estudio tuvo como objetivo analizar la acción de los fármacos que actúan sobre la Angiotensina (TA) en presencia de COVID19 en comparación con otros antihipertensivos, así como identificar la los principales. evidencia sobre el tema presentado hasta ahora. Se trata de una revisión integradora de la literatura que contiene 34 artículos seleccionados según los criterios de inclusión, entre enero / 2020 a febrero / 2021, en las bases de datos PubMed, Embase, Scopus y Web of Science. Los resultados no muestran una relación causal entre el aumento de la infección por COVID-19 y el uso de inhibidores del RAAS, sino un posible efecto protector de estos frente a la manifestación grave de la enfermedad debido a la inhibición de las enfermedades proinflamatorias de AT II. Así, aproximadamente la cuarta parte de los estudios defendieron la continuidad del uso y el factor de protección de los bloqueadores de RAAS en detrimento de las otras clases de fármacos antihipertensivos que no modulan el RAAS. Se constató, entonces, que se debe mantener el tratamiento antihipertensivo, ya que no empeora el pronóstico ante la infección por Sars-CoV-2. Sin embargo, los estudios son principalmente observacionales y, por lo tanto, no pueden establecer relaciones causales sólidas. Por esta razón, se necesitan ensayos controlados aleatorios sólidos para comprender mejor este tema.

Palabras clave: Agentes Antihipertensivos; Inhibidores de la enzima convertidora de angiotensina; Hipertensión; SARS-CoV-2; COVID-19.

\section{Introduction}

In January 2020 the world was surprised by the declaration of the World Health Organization (WHO) of the Public Health Emergency of International Importance (ESPII). The cause was the outbreak of the new coronavirus, Sars-CoV-2, which causes the disease COVID-19. With a high rate of transmissibility and virulence, the virus caused a significant number of cases spread across all continents, which culminated, in March 2020, in the establishment of a pandemic (Organização Pan-Americana de Saúde, 2021).

During the appearance of the first cases of the disease, it was thought that this was another form of common pneumonia.

This was because the symptoms were similar to a Flu Syndrome - cough, runny nose, fever, headache, odynophagia. However, with the advance of the pandemic, there were multiple varieties of symptoms associated with COVID-19 that were not related to the respiratory system like myalgia, gastrointestinal disorders, dysgeusia, anosmia, and others (Organização Pan-Americana de Saúde, 2021).

During the systemic phase, due to the inflammatory character, there is a diffuse induction in the prothrombotic state, due to the fact that COVID-19 causes a generalized endotheliitis simultaneously with a new pneumonia. This, in many situations, can involve with high percentage of mortality (Dantas et al., 2021; Libby \& Lüscher, 2020; Trump et al., 2020).

This phenomenon is related to the way the virus infects cells in the human body. Pathophysiology occurs from the interaction of the virus's Speak (S) protein with the Angiotensin-Converting Enzyme 2 (ACE2), a transmembrane protein present in many human cells, especially in the vascular endothelium (Delpino \& Quarleri, 2020; Shibata et al., 2020).

The important role of ACE2 in the Renin-Angiotensin-Aldosterone System (RAAS), essential for the maintenance of homeostasis of Blood Pressure (BP), raise doubts about the management of hypertensive patients, who are part of an important risk group for the development of the severe form of COVID-19 (Grasselli et al., 2020; Jakhmola et al., 2020).

According to a large multicenter study that tested the relation between hypertension and COVID-19, 24\% of patients with severe disease were hypertensive, whereas among those who manifested the mild form, only $14 \%$ were hypertensive (Guan et al., 2020). 
Therefore, the use of antihypertensive drugs that target the angiotensin (AT) peptide, such as Angiotensin Conversion Enzyme Inhibitors (ACEI) and Angiotensin Receptor Blockers (ARB), has become a concern in the sense to understand whether or not they promote greater potential risks to the severity of COVID-19 (Ruilope et al., 2020; Salazar et al.,2020; Trump et al., 2020).

In this perspective, the present review aimed to evaluate the implication of drugs that act on AT in the presence of COVID-19 infection compared to other antihypertensive drugs, as well as to identify the main conclusions on the subject in a scientific way validated.

\section{Methodology}

An integrative literature review was carried out based on the identification of the theme and selection of the research question; establishment of inclusion and exclusion criteria; evaluation of the included studies; definition of the information to be extracted from the selected studies; interpretation of results, synthesis and presentation of the scientific evidence found.

The following keywords were used as descriptors obtained from the MeSH platform (Medical Subject Headings) PubMed/Medline: Antihypertensive Agents, Angiotensin-Converting Enzyme Inhibitors, Hypertension, SARS-CoV-2, COVID19. Data collection took place between January and February 2021 in the PubMed, Embase, Scopus and Web of Science databases, using the select descriptors. Original research articles, whose theme answered the guiding question, published between January 2020 and February 2021 were included. Studies that addressed other themes were excluded, did not have a full text released or at least one keyword in the title and summary.

An exhaustive reading of the titles and abstracts was carried out, independently, blindly, by two authors, with a third reviewer in case of divergence, to ensure that the manuscripts contemplated the guiding question of the review and met the inclusion criteria and exclusion established. The analysis of the data in this review was carried out descriptively and discussed in two ways: implication of drugs that act on angiotensin when at the time of infection by COVID-19; use of antihypertensive drugs not associated with angiotensin in patients with COVID-19 (Pereira et al., 2018).

\section{Results}

The searches in the databases searched resulted in 161 specific studies on the topic (Figure 1). After the exclusions, 113 studies were read in full, of which 37 were included in the results of this view. Figure 1 summarizes the selection process for the included studies in a flowchart. In addition, we have included the websites of the Pan American Health Organization / World Health Organization and the European Society of Cardiology as we consider safe and important sources for the theme of this study. 
Figure 1. Flowchart of the selection of included studies.

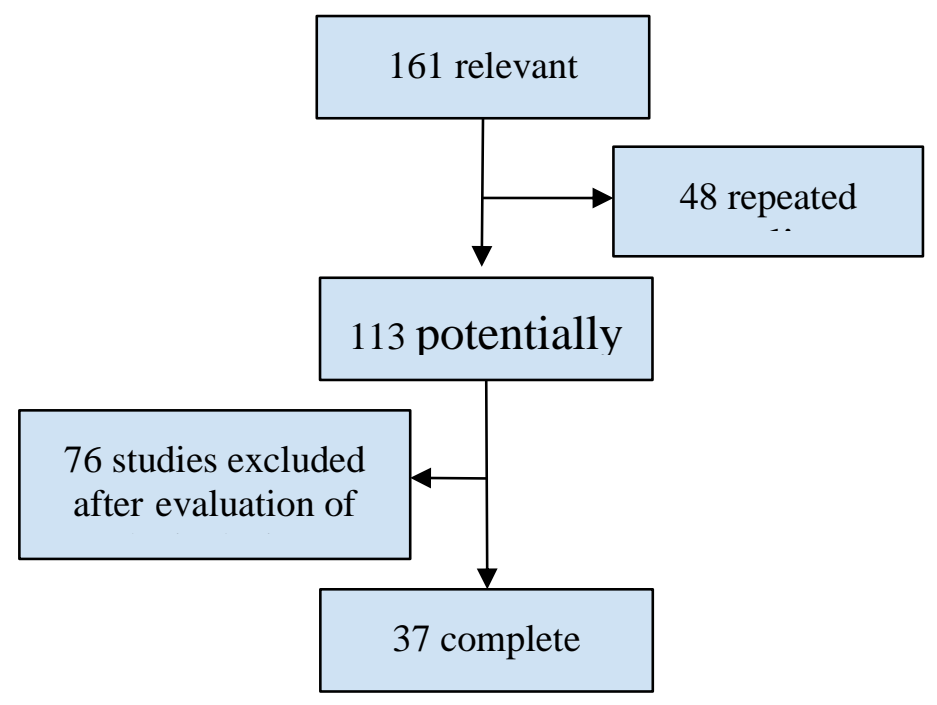

Source: Authors (2021)

The selected studies highlighted the expression of ACE2 against COVID-19 infection, correlating the effects of drugs of the ACEI and RAAS classes in hypertensive patients diagnosed with Sars-CoV-2.

The second point observed was the use of ACEI and RAAS, which can modulate the inflammatory phase of COVID19 and present a protective effect to lung injuries and other complications caused by the disease.

Although studies directed only to the use of antihypertensive non-blocking RAAS have not been found, some observational studies have compared beta-blockers, calcium channel blockers (CCB) and thiazide diuretics, to identify whether these classes of drugs influence the critical progression of COVID-19 or whether they should be replaced by the group of ACEI and RAAS drugs.

\section{Discussion}

Patients with hypertension, especially decompensated, are more vulnerable to systemic complications since this comorbidity interacts directly with the functioning of the organs by promoting exacerbated inflammatory responses. Thus, these patients are predisposed to develop severe pneumonia or fatal organic injury when infected with Sars-CoV-2 (Trump et al., 2020; Monte, et al. (2020).

The new coronavirus binds to ACE2 through its protein Spike (S) to enter the cells present in the salivary glands, respiratory tract, pulmonary epithelium, intestine, kidneys and blood vessels and promote the disease itself. Since TA is one of the main targets of antihypertensive therapy, it is worth understanding its participation associated with Sars-CoV-2 infection (Delpino \& Quarleri, 2020; Marin, 2020; Nejat \& Sadr, 2020).

The ACE cleaves angiotensin I to generate type II and it binds and activates the Angiotensin II Receptor Type 1 (AT1R), in the classic RAAS pathway. The effect of this is the generation of vasoconstriction and pro-inflammatory effects with a consequent increase in blood pressure. (Delpino \& Quarleri, 2020; Marin, 2020; Nejat \& Sadr, 2020).

Meanwhile, on the other axis of RAAS, the ACE2 cleaves AT II into AT1-7 and AT I into AT 1-9 providing vasodilatation, anti-inflammatory and anti-fibrotic mechanisms with negative feedback in RAAS. Furthermore, ACE is also able to cleave AT 1-9 in 1-7 (Delpino \& Quarleri, 2020; Marin, 2020; Gurwitz, 2020; Reynolds et al., 2020; Trump et al., 2020). 
In this sense, the connection between Sars-CoV-2 and ACE2 causes negative regulation in the enzyme, which reduces its quantity and activity. The result of this is the excess of angiotensin, hyperstimulation of AT1R and increased pulmonary vascular permeability, which culminates in the accumulation of fluid in the alveolar sacs and increases the likelihood of lung injuries (Cheng et al., 2020; Delpino \& Quarleri, 2020; Gurwitz, 2020; Nejat \& Sadr, 2020).

When understanding the behavior of the virus in ACE2 and its influence in AT1R, it started to question the implication of drugs that modulate RAAS, such as ARB and ACEI in patients with COVID-19. This is because two conflicting conclusions have emerged from studies that address the topic (Singh et al., 2020).

The first argues that the use of these drugs leads to an increase in the expression of ACE2, and this would facilitate infection by the virus, since this protein is the site of entry of Sars-CoV-2 into cells (Fang, Karakiulakis \& Roth, 2020; Gao, et al., 2020; Malhotra, Hepokoski, McCowen \& Y-J Shyy, 2020; Reynolds et al., 2020). While the second refers to a possible protective effect of these drugs during the inflammatory phase of COVID-19 (Cheng et al., 2020; Marin, 2020; Nejat \& Sadr, 2020).

Regarding the first point, the preclinical studies that evaluated the increase in the expression of ACE2 associated with the use of these drugs showed conflicting results. Therefore, there is still no consensus that these drugs alter the regulation of ACE2 (Gao, et al., 2020; Ramírez-Sagredo et al., 2020).

However, even if these drugs lead to an increase in the expression of ACE2, until now, the literature does not show an increase in the probability by patients who use these medications (Gao, et al., 2020; Reynolds et al., 2020; Sardu et al., 2020).

Harmony R. Reynolds et al., in an observational study, found that hypertensive patients using antihypertensive drugs, when compared to hypertensive patients without pharmacological treatment, did not show any difference in the percentage of infected (Reynolds et al., 2020).

Possibly, these findings are related to the fact that the increase in ACE2 does not define, separately, the infectivity of Sars-CoV-2 in the human organism, since the virus, to fuse its protein S to ACE2, depends on the serine protease-2 transmembrane (SP2TM), expressed in the lungs and ileum, therefore, it is not altered only by the use of ARB or ACEI (Nejat \& Sadr, 2020).

The concern persists for the expression of the ACE2 and SP2TM in the endothelial cells, the direct or indirect injury by the Sars-CoV-2 in the endothelium, increased by vascular permeability, predisposing to pulmonary fibrosis and RAAS, since the increase in permeability results in acute respiratory failure, bilateral pulmonary infiltrates and non-cardiogenic pulmonary edema (Nejat \& Sadr, 2020).

Associated with hypertension, inflammatory cytokine storm and coagulation cascade, elevated vascular permeability induces other complications, endotheliitis, myocardial injury, venous thromboembolism, ischemic stroke, ischemic heart disease, which determines the severity of COVID-19 (Ruilope et al., 2020; Shibata et al., 2020).

Regarding the second point, the possible positive effect of antihypertensive drugs is explained by the mechanism of action of these drugs. That is, the ARB class antagonizes ATII by blocking AT1R (Alnajjar, et al., 2020; Nejat \& Sadr, 2020). ACEI does this by reducing the action of ACE, which reduces the amount of ATII, without inhibiting ACE2, by compromising the conversion of ATI into II and then the activation of AT1R (Cheng et al., 2020; Nejat \& Sadr, 2020; Rothlin et al., 2020).

The result of all the above processes is to avoid the vasoconstrictor, pro-inflammatory and fibrinous effects of this peptide, which can alleviate the cytokine storm characteristic of the inflammatory phase of COVID-19 (Alnajjar et al., 2020; Meng et al., 2020; Nejat \& Sadr, 2020).

Some studies have already demonstrated some positive effect of these drugs to antihypertensive drugs that do not inhibit RAAS to mortality in COVID-19, especially from ACEI, although ARB also appears to reduce the risk of the criticality of the disease (Gao, et al., 2020; Gurwitz, 2020; Trump et al., 2020). 
A study published by Trump et al. (2020) concluded that in addition to the ACEI and ARB drugs not increasing the Sars-CoV-2 viremia, they modulate a protective response in hypertensive patients with/without heart disease since they identified a greater number of patients with COVID-19 in severe form (approximately 70\%) without previous treatment using the ACEI or ARB (Trump et al., 2020).

Thus, when comparing ACEI with ARB, there was a considerable decline in critical cases, a reduced risk of worsening the disease, showing a beneficial effect of ACEI against Sars-CoV-2 infection (Trump et al., 2020).

In contrast, Nejat and Sadr defended the potential effect of ARB, especially losartan, on the attenuation of RAAS and vascular inflammatory reaction in the face of the cytokine storm caused by COVID-19, being considered as having high antiviral activity, whether isolated or associated with other medications, such as with the antineoplastic imatinib (Alnajjar, et al., 2020; Nejat \& Sadr, 2020).

The combination of valsartan (ARB) with sacubitril (neprilysin inhibitor) has also been suggested by other authors as potential anti-inflammatory drugs for COVID-19 (Ruilope et al., 2020).

Semenzato et al. structured a retrospective cohort of more than 1.8 million hypertensive patients, based on the analysis of the French National Health System database, to assess the risk of COVID-19 infection according to the antihypertensive drug used. To minimize confounding factors, only hypertensive patients without other comorbidities were included in the study, who were divided into three groups, according to the medication in use: ACEI, ARB or CCB. The study result associated a lower risk of infection, intubation or death by COVID-19 with ACEI and ARB, when compared to CCB (Semenzato et al., 2021).

Both ACEI and ARB can positively regulate the concentration of AT1-9 and ACEI in the action of AT 1-7, which have cardioprotective vasodilatory, antihypertrophic and anti-fibrotic actions, being able to reduce the progression to insufficiency pulmonary (Abajo et al., 2020; Ramírez-Sagredo et al., 2020; Trump et al., 2020).

Abajo et al. (2020) and Delpino and Quarleri (2020) identified a higher proportion of AT 1-7 in patients with RAAS who survived, as well as a direct proportion between serum concentrations of ATII, viral load and lung damage in patients with COVID-19. These determinations corroborate to defend the use of RAAS blockers in COVID-19 (Ramírez-Sagredo et al., 2020; Trump et al., 2020).

The analyzed studies have no evidence to promote strong causal relations, but they play an important role in formulating hypotheses. Therefore, the idea that the continued treatment of hypertensive patients with these medications, during COVID-19 infection, is superior to not using these drugs (Gao, et al., 2020; Reynolds et al., 2020; Sardu et al., 2020).

This idea is in line with the observational study developed by Gao et al. (2020) who observed a lower mortality rate due to COVID-19 among hypertensive patients treated with antihypertensive drugs when compared to hypertensive patients without treatment. (Gao et al.,2020).

This is an important point because, throughout the pandemic, some recommendations related to ACEI and ARB were formulated, which advocated the replacement of these classes of antihypertensive drugs with drugs that do not inhibit RAAS, such as CCB (Antwi-Amoabeng et al., 2020; Fang et al., 2020).

The change in therapeutic strategy in hypertensive patients involves several variables, such as age, sex, obesity, comorbidities (diabetes, for example), which contribute to the severity of the pathological presentation and interfere with the expression of ACE2. Thus, the interruption or alteration in the treatment of these patients should not occur abruptly, since it causes greater susceptibility to acute myocardial infarction, brain stroke and death (Abajo et al. 2020, Goes et al. 2020; Marin, 2020; Trifirò et al. 2020).

Taking this risk without robust scientific evidence is inadvisable as studies show that these classes of antihypertensive drugs are not associated with increased susceptibility, nor with a worse prognosis in the face of COVID-19 infection (Alnajjar, et al., 2020; Marin, 2020; Gurwitz, 2020; Reynolds et al., 2020). 
Based on the above, the European Society of Cardiology's Hypertension Council recommends that doctors and patients follow their usual antihypertensive treatments (Hypertension ECo., 2020).

The pharmacodynamics of antihypertensive drugs has not yet demonstrated safety and scientific effectiveness in the pathogenesis of COVID-19. For this reason, it is essential to compare the main classes that interact or not with the mechanism of cell entry of the new coronavirus in the human body to determine viral load and pathological severity (Antwi-Amoabeng et al., 2020; Ruilope et al., 2020; Abajo et al., 2020; Solaimanzadeh, 2020).

In this sense, Jaiyong Kim et al. evaluated big data from the Korean national health system on tens of thousands of hypertensive patients with COVID-19 undergoing treatment with ARB, ACEI, CCB and diuretics. Data analysis showed that even patients with a shorter duration of antihypertensive treatment were less susceptible to infection (Kim et al., 2020).

In a similar study in southeastern Catalonia, these classes of antihypertensive drugs were not associated with an increased risk of infection by Sars-CoV-2 (Vila-Corcoles et al., 2020).

A case-control study compared the use of antihypertensive drugs associated or not with RAAS. Although the use of ACEI and ARB is more frequent among the population evaluated, CCB, beta-blockers and mineralocorticoid receptor antagonists have shown no relation with the risk of COVID-19 infection and the severity of the disease (Mancia et al., 2020).

However, patients using loop diuretics had a higher risk for infection, associated with severe heart disease, chronic kidney disease and other organic disorders, which increase the morbidity and mortality of COVID-19 (Mancia et al., 2020 ; Shibata et al., 2020).

Cadegiani et al. suggested that the use of spironolactone, a mineralocorticoid receptor antagonist, a potassium-sparing diuretic, is more effective than ACEI and ARB. In addition to elevating circulating ACE2 to the detriment of those linked to the pulmonary membranes, it has a greater protective potential against Sars-Cov-2, reduces the expression of androgen-mediated SP2TM because it is anti-androgenic and has an anti-inflammatory action on the lungs, heart and kidneys. Depending on this hypothesis, spironolactone should be used for the first symptoms, before the disease progresses with complications (Cadegiani et al., 2020).

Concerned about the uncertainties in the use of ACEI and RAB, Antwi-Amoabeng et al. (2020) suggested that alternative drugs could be used more safely in hypertensive patients with COVID-19. Verapamil, for example, CCB, does not affect the expression of ACE2 and improves the course of viral myocarditis.

Another alternative is carvedilol, a beta1 and alpha1 non-selective blocker, which, in addition to acting on viral myocarditis by inhibiting peroxidants, reduces heart rate, inhibits myocyte damage and remodels the ventricles in myocarditis (Antwi-Amoabeng et al., 2020).

Solaimanzadeh chose dihydropyridine CCB, nifedipine and amlodipine as a treatment that minimizes the need for intubation, mechanical ventilation and reduces COVID-19 mortality in hypertensive elderly patients. These drugs act on pulmonary hypertension without reducing arterial oxygenation or causing systemic hypotension, preserve right heart activity and are effective in the management of patients with chronic obstructive pulmonary disease associated with pulmonary hypertension, in addition to working to combat hypoxia resulting from infection by Sars-Cov-2 (Solaimanzadeh, 2020).

Finally, Abajo et al. (2020) agree that acting or not in RAAS, these classes of drugs do not interfere in the clinical course of Sars-CoV-2, however, CCB are safer because they do not increase the expression of ACE2 (Abajo et al., 2020; Fang et al., 2020; Solaimanzadeh, 2020). 


\section{Conclusion}

The pathophysiological mechanisms of Sars-CoV-2 indicate the mediation of ACE2 present in the lungs, heart and other organs compromised by the disease. Thus, the viral load and critical presentation or not of COVID-19 may be related to the level of expression of ACE2 in the body.

In this perspective, at the beginning of the COVID-19 pandemic, the hypothesis of RAAS blockers increasing the risk of Sars-CoV-2 infection led to the recommendation that the use of ACEI and ARB should be replaced by other classes of antihypertensive drugs.

However, the present review demonstrated that these drugs have protective effects by increasing the expression of circulating ACE2, as well as AT1-7 and AT1-9 when compared to drugs not acting in the RAAS.

In conclusion, what was observed is that acting or not in blocking the RAAS, such classes of antihypertensive drugs do not aggravate the prognosis in front of Sars-CoV-2 infection. However, scientific evidence supports the preference for the use of ACEI and ARB. Therefore, even if the literature is not convinced about the best approach, the change in the dose of medication used as well as the therapeutic interruption can result in increased morbidity and mortality in hypertensive patients with COVID19.

For the future, robust randomized clinical trials must seek a better understanding of the causal relationship between the classes of antihypertensive drugs and the morbidity and mortality of COVID-19. For a while, it is essential to establish guidelines following the scientific literature, advocating to avoid sudden changes in the pharmacological therapeutic strategies of hypertensive patients.

\section{References}

Abajo, F. J., Rodríguez-Martín, S., Lerma, V., Mejía-Abril, G., Aguilar, M., \& García-Luque, A., et al. (2020). Use of renin-angiotensin-aldosterone system inhibitors and risk of COVID-19 requiring admission to hospital: a case-population study. Lancet. 395(10238), 1705-1714. https://doi.org/10.1016/S01406736(20)31030-8.

Alnajjar, R., Mostafa, A., Kandeil, A., \& Al-Karmalawy, A. A. (2020). Molecular docking, molecular dynamics, and in vitro studies reveal the potential of angiotensin II receptor blockers to inhibit the COVID-19 main protease. Heliyon. 6(12), e05641. https://doi.org/10.1016/j.heliyon.2020.e05641.

Antwi-Amoabeng, D., Beutler, B. D., Moody, A. E., Kanji, Z., Gullapalli, N., \& Rowan, C. J. (2020). Management of hypertension in COVID-19. World J Cardiol. 12(5), 228-230. https://doi.org/10.4330/wjc.v12.i5.228.

Cadegiani, F. A., Goren, A., \& Wambier, C. G. (2020). Spironolactone can provide protection against SARS-CoV-2: androgen targets, angiotensin-converting enzyme 2 (ACE2) and renin-angiotensin-aldosterone system (RAAS). J Med Hypotheses. 143, 110112. https://doi.org/10.1016 / j.mehy.2020.110112.

Cheng, H., Wang, Y., \& Wang, L-Q. (2020). Organ-protective effect of angiotensin-converting enzyme 2 and its effect on the prognosis of COVID-19. J Med Virol. 92, 726 - 730. https://doi.org/10.1002/jmv.25785.

Dantas, T. C. de A. ., Gomes, A. C. A. ., Lima, I. P. C. ., Lucas , B. B. ., Aguiar, M. R. de ., Cavalcanti, T. C. de H. ., Pinheiro, F. I. ., Rêgo, A. C. M. ., \& AraújoFilho, I. (2021). Corticosteroid therapy in patients with severe COVID-19. Research, Society and Development, 10(1), e58910112114. https://doi.org/10.33448/rsd-v10i1.12114.

Delpino, M. V., \& Quarleri, J. (2020) SARS-CoV-2 Pathogenesis: Imbalance in the Renin-Angiotensin System Favors Lung Fibrosis. Front Cell Infect Microbiol. 10(340). doi: https://doi.org/10.3389/fcimb.2020.00340.

Fang, L., Karakiulakis, G., \& Roth, M. (2020). Are patients with hypertension and diabetes mellitus at increased risk for COVID-19 infection? Lancet Respir Med. 8(4), e21. https://doi.org/10.1016/S2213-2600(20)30116-8.

Gao, C., Cai, Y., Zhang, K., Zhou, L., \& Zhang, Y., et al. (2020). Association of hypertension and antihypertensive treatment with COVID-19 mortality: a retrospective observational study. Eur Heart J. 41(22), 2058-2066. https://doi.org/10.1093/eurheartj/ehaa433.

Goes, A. B., Cardoso, B. B., Tavares, F. A., Monte, R. R., et al. (2020). COVID-19 and Nervous System: Under Estimated Clinical and Prognostic Aspects. International Journal of Neurology Neurotherapy, 7(100), 1-7. https://doi.org/10.23937/2378-3001/1410100.

Grasselli, G., Greco, M., Zanella, A., Albano, G., Antonelli, M., \& Bellani, G., et al. (2020). COVID-19 Lombardy ICU Network. Risk Factors Associated With Mortality Among Patients With COVID-19 in Intensive Care Units in Lombardy, Italy. JAMA Intern Med. 180(10), 1345-1355. https://doi.org/10.1001/jamainternmed.2020.3539.

Guan, W., Ni, Z., Hu, Y., Liang, W., Ou, C., \& He, J., et al. (2020). Clinical characteristics of coronavirus disease 2019 in China. N Engl J Med. 382 , 1708-20. https://doi.org/10.1056/NEJMoa2002032. 
Gurwitz, D. (2020). Angiotensin receptor blockers as tentative SARS-CoV-2 therapeutics. Drug Dev Res. 81, 537-540. https://doi.org/10.1002/ddr.21656.

Hypertension ECo. (2020). Position Statement of the ESC Council on Hypertension on ACEInhibitors and Angiotensin Receptor Blockers [internet]. [acesso em 2021 Fev 20]. Disponível em: https://www.escardio.org/Councils/Council-on-Hypertension-(CHT)/News/position-statement-of-the-esc-councilonhypertension-on-ace-inhibitors-and-ang.

Jakhmola, S., Indari, O., Baral, B., Kashyap, D., Varshney, N., Das A., Chatterjee, S., \& Jha, H. C. (2020) Comorbidity Assessment Is Essential During COVID19 Treatment. Front Physiol. 11(984). https://doi.org/10.3389/fphys.2020.00984.

Kim, J., Kim, D. W., Kim, K. I., Kim, H. B., Kim, J. H., \& Lee, Y. G., et al. (2020) Korean Society of Hypertension. Compliance of Antihypertensive Medication and Risk of Coronavirus Disease 2019: a Cohort Study Using Big Data from the Korean National Health Insurance Service. J Korean Med Sci. $35(25)$, e232. https://doi.org/10.3346/jkms.2020.35.e232.

Libby, P., \& Lüscher, T. (2020). COVID-19 is, in the end, an endothelial disease. Eur Heart J. 41(32), 3038-3044. https://doi.org/10.1093/eurheartj/ehaa623.

Malhotra, A., Hepokoski, M., McCowen, K. C. \& Y-J Shyy J. (2020). ACE2, Metformin, and COVID-19. iScience. 23(9), 101425. https://doi.org/10.1016/j.isci.2020.101425.

Mancia, G., Rea, F., Ludergnani, M., Apolone, G., \& Corrao, G. (2020). Blockers of the renin-angiotensin-aldosterone system and the risk of Covid-19. $N$ Engl J Med. 382(25), 2431-2440. https://doi.org/10.1056 / NEJMoa2006923.

Marin, G. H. (2020). Facts and reflections on COVID-19 and anti-hypertensives drugs. Drug Discov Ther. 14(2), 105-106. https://doi.org/10.5582/ddt.2020.01017.

Meng, J., Xiao, G., Zhang, J., He, X., \& Ou, M., et al. (2020). Renin-angiotensin system inhibitors improve the clinical outcomes of COVID-19 patients with hypertension. Emerg Microbes Infect. 9(1), 757-760. https://doi.org/10.1080/22221751.2020.1746200.

Monte, R. R., Tavares, F. A., Cardoso, B. B., Goes, A. B., et al. (2020). Covid-19 Pandemic and Health Professionals: Practical Approaches. International Journal of Critical Care Emergency Medicine, 6(108), 1-9. https://doi.org/10.23937/2474-3674/1510108.

Nejat, R., \& Sadr, A. S. (2020). Are losartan and imatinib effective against SARS-CoV2 pathogenesis? A pathophysiologic-based in silico study. In Silico Pharmacol. 9(1), 1. https://doi.org/10.1007/s40203-020-00058-7.

Organização Pan-Americana de Saúde; Organização Mundial da Saúde [homepage na internet]. (2021). Folha informativa COVID-19 - Escritório da OPAS e da OMS no Brasil. [acesso 2021 Fev 09]. Disponível em: https://www.paho.org/pt/covid19.

Pereira, A. S., Shitsuka, D. M., Parreira, F. J., \& Shitsuka, R. (2018). Metodologia Da Pesquisa Científica (1st ed.). Santa Maria: Universidade Federal de Santa Maria.

Ramírez-Sagredo, A., Ramírez-Reyes, A., Ocaranza, M. P., Chiong, M., Riquelme, J. A., \& Jalil, J. E., et al. (2020). Anti hypertensive agents in patients with COVID-19. Rev Chil Cardiol. 39(1), 66-74. http://dx.doi.org/10.4067/S0718-85602020000100066.

Reynolds, H. R., Adhikari, S., Pulgarin, C., Troxel, A. B., Iturrate, E., \& Johnson, S. B, et al. (2020). Renin-Angiotensin-Aldosterone System Inhibitors and Risk of Covid-19. N Engl J Med. 382(25), 2441-2448. https://doi.org/10.1056/NEJMoa2008975.

Rothlin, R. P., Vetulli, H. M., Duarte, M., \& Pelorosso, F. G. (2020). Telmisartan as tentative angiotensin receptor blocker therapeutic for COVID-19. Drug Dev Res. 81(7), 768-770. https://doi.org/10.1002/ddr.21679.

Ruilope, L. M., Tamargo, J., \& Ruiz-Hurtado, G. (2020). Renin-angiotensin system inhibitors in the COVID-19 pandemic: consequences of antihypertensive drugs. Eur Heart J. 41(22), 2067-2069. https: //doi.org/10.1093/eurheartj/ehaa487.

Salazar, M., Barochiner, J., Espeche, W., \& Ennis, I. (2020). COVID-19, hipertensión y enfermedad cardiovascular [COVID-19 and its relationship with hypertension and cardiovascular disease]. Hipertens Riesgo Vasc. 37(4), 176-180. https://doi.org/10.1016/j.hipert.2020.06.003.

Sardu, C., Maggi, P., Messina, V., Iuliano, P., Sardu, A., \& Iovinella, V., et al. (2020). Could Anti-Hypertensive Drug Therapy Affect the Clinical Prognosis of Hypertensive Patients With COVID-19 Infection? Data From Centers of Southern Italy. $J$ Am Heart Assoc. 9(17), e016948. https://doi.org/10.1161/JAHA.120.016948.

Semenzato, L., Botton, J., Drouin, J., Baricault, B., Vabre, C., \& Cuenot, F., et al. (2021). Antihypertensive Drugs and COVID-19 Risk: A Cohort Study of 2 Million Hypertensive Patients. Hypertension. 77(3), 833-842. https://doi.org/10.1161/HYPERTENSIONAHA.120.16314.

Shibata, S., Arima, H., Asayama, K., Hoshide, S., Ichihara, A., \& Ishimitsu, T., et al. (2020). Hypertension and related illnesses in the COVID-19 era: a report by the Japanese Hypertension Society Task Force on COVID-19. Hypertens Res. 43(1), 1028-1046. https://doi.org/10.1038/s41440-020-0515-0.

Singh, A. K., Gupta, R., \& Misra, A. (2020). Comorbidities in COVID-19: Outcomes in hypertensive cohort and controversies with renin angiotensin system blockers. Diabetes Metab Syndr. 14(4), 283-287. https://doi.org/10.1016/j.dsx.2020.03.016.

Solaimanzadeh, I. (2020). Nifedipina e amlodipina estão associadas a mortalidade melhorada e risco reduzido de intubação e ventilação mecânica em pacientes idosos hospitalizados por COVID-19. Cureus. 12(5), e8069. https://doi.org/10.7759/cureus.8069.

Trifirò, G., Crisafulli, S., Andò, G., Racagni, G., \& Drago, F. (2020). Italian Society of Pharmacology. Should Patients Receiving ACE Inhibitors or Angiotensin Receptor Blockers be Switched to Other Antihypertensive Drugs to Prevent or Improve Prognosis of Novel Coronavirus Disease 2019 (COVID-19)? Drug Saf. 43(6), 507-509. https://doi.org/10.1007/s40264-020-00935-2.

Trump, S., Lukassen, S., Anker, M. S., Chua, R. L., Liebig, J., \& Thürmann L., et al. (2020) Hypertension delays viral clearance and exacerbates airway hyperinflammation in patients with COVID-19. Nat Biotechnol. https://doi.org/10.1038/s41587-020-00796-1. 
Research, Society and Development, v. 10, n. 6, e41510615977, 2021 (CC BY 4.0) | ISSN 2525-3409 | DOI: http://dx.doi.org/10.33448/rsd-v10i6.15977

Vila-Corcoles, A., Satue-Gracia, E., Ochoa-Gondar, O., Torrente-Fraga, C., Gomez-Bertomeu, F., \& Vila-Rovira, A., et al. (2020). Use of distinct antihypertensive drugs and risk for COVID-19 among hypertensive people: A population-based cohort study in Southern Catalonia, Spain. J Clin Hypertens (Greenwich). 22(8), 1379-1388. https://doi.org/10.1111/jch.13948. 